\title{
INTEGRATING REMOTE-SENSED AND HISTORICAL GEODATA TO ASSESS INTERACTIONS BETWEEN RURAL BUILDINGS AND AGROFORESTRY LAND
}

\author{
Giuseppe CILLIS, Dina STATUTO*, Pietro PICUNO \\ University of Basilicata, Potenza, Italy
}

Received 09 September 2020; accepted 15 January 2021

\begin{abstract}
The rural built heritage constitutes a unique example, due to architectural and technical issues, which plays a central role in the formation of rural landscape. In this research, interactions between rural buildings and the surrounding land have been examined. Two case studies exemplifying some of typical dynamics of some internal mountain areas of Mediterranean region have been considered. These areas are located in Basilicata Region (Southern Italy) and suffer from land and rural buildings heritage abandonment, as well as from the concurrent disappearance of agroforestry systems with high ecological value. A multi-chronological geo-database incorporating different land cover datasets over a period of 62 years (1955-1988-2008-2017) has been implemented into a GIS to assess relationships between some rural buildings and the surrounding land have been then assessed. This has been achieved by integrating different types of remote-sensed geodata: historical aerial photos, digital orthophotos and satellite images. The analyses carried out have shown that the intensity of land abandonment can also be related to the type of rural building and prevalent agricultural activity. Moreover, thanks to this methodology, it has been possible to produce several spatial information useful to support public decisionmakers at different level.
\end{abstract}

Keywords: rural built heritage, Basilicata region, agroforestry land, cartography, aerial photos, satellite images, GIS, FoSS.

\section{Introduction}

The importance of the agroforestry land is recognized at scientific level as a sustainable land management practice because it provides different ecosystem services, reduces direct anthropic negative impacts and a sustainable system of food production (Nair, 1993; Buttoud et al., 2013; Lasco et al., 2014; Burgess \& Rosati, 2018). Moreover, it plays a key role in achieving integrated and connected rural and urban development (Saikia et al., 2017). In addition to having a high naturalistic value, the agroforestry land also has a huge value in terms of landscape, cultural and historical value as they are representative of many historical rural landscapes of the Mediterranean region (Pardini, 2009; Moreno et al., 2018; Santiago-Freijanes et al., 2018; Hillbrand et al., 2017; Statuto \& Picuno, 2017; Picuno et al., 2017). Agroforestry land is traditionally a key element of landscape management. Complex systems, based on the integration of crop-livestock-fruit/forestry trees, have provided a wide variety of agricultural products and other ecosystem services (e.g. erosion control, biodiversity conservation and visual quality). These traditional systems for centuries and are still operating in marginal and less profitable areas were used. The integration of olive trees (and sometimes vineyards) with crops and free grazing was widely practised (Pardini, 2009; Paris et al., 2019).

*Corresponding author. E-mail: dina.statuto@unibas.it 
Another important element in conjunction with the land transformations and landscape is represented by rural buildings and in particular those linked to a traditional agricultural activities (Cillis et al., 2020a). The rural building is an interesting technological model, designed with the aim of creating good environmental conditions for animals, plants and workers engaged in daily operations. Rural building role is closely related to what happens in surrounding environment. In inner areas, traditional rural buildings have been restored to meet current needs and regulations and in some cases new rural buildings have been built from scratch but in spatial continuity with traditional ones, so in these cases there is also a temporal continuity between the rural buildings and the surrounding area (Statuto \& Picuno, 2017). Moreover, when rural buildings respond to concepts typical of agroecology, as in the case of traditional and non-intensive agricultural activities, the link with the territory is even stronger because they can have a direct impact on biodiversity and in particular with the conservation/restoration of grassland (McKenzie et al., 2011; Haller \& Bender, 2018). However, in recent decades, mostly the Mediterranean territories and landscapes have changed a lot (De Montis et al., 2017). In Mediterranean region, indeed, in flat areas close to large urban and industrial centres, there has been an important land consumption (Strollo et al., 2020; Baldantoni et al., 2019; Belda-Carrasco et al., 2019) with consequent reduction of ecological connectivity and substitution of agroforestry systems. On the other hand, in hilly (Statuto et al., 2016) and mountainous areas (Malandra et al., 2019) the land abandonment is increasing the forest area to the disadvantage of traditional and heterogeneous agricultural areas within which the agroforestry land falls (Cillis et al., 2019a). In addition, there are several landscape transition scenarios for the whole of Europe (Pinto-Correia et al., 2018), demonstrating the need for both local and global approaches. Given the need for planning, that is increasingly focused to the various territorial identities, in these situations it is essential to study how the relationship between different uses and land cover is changing in order to safeguard the ecological balance of complex agroforestry systems. To assess quantitatively and qualitatively these changes (González-Puente et al., 2014), a wide variety of different tools, approaches and techniques, has been tested and developed to include many aspects (from the spatial to the perceptual component).

Therefore, considering the close relationship between land, landscape and farm buildings (Ledda et al., 2019), it is necessary to implement methodologies for the assessment of changes in the rural land that also include the built agricultural heritage. In order to include the temporal dimension in these spatial studies, it is essential to integrate several types of data, often very varied and requiring different pre-processing and elaboration techniques. This is possible using historical maps together with other types of cartography and aerial photos, that allows to recover territorial geodata for very long time periods. Even if complex to manipulate and with some errors, they are indeed the only source to process spatialized land cover and land use data, especially when changes are relevant (Amici et al., 2017). In addition, the inclusion of geodata from new generation satellite imagery is essential, since the spatial and temporal resolution, ensures a highly detailed land cover mapping (Van Tricht et al., 2018; Statuto et al., 2019a). In addition, they can provide ancillary or predictive information that are essential for the investigation of many spatial and landscape issues, such as biodiversity and the impacts of intensive agriculture (Valerio et al., 2020; Lanorte et al., 2017; Rocchini et al., 2018).

In this study, the relationships between rural buildings heritage and the surrounding land have been surveyed through a comprehensive geodatabase that incorporates several geodata from topographical maps, aerial photos, ortophotos and satellite images which has been implemented into a GIS. This approach has made it possible to evaluate the dynamics of the land around rural buildings in order to prepare models for the determination of land cover dynamics both in qualitative and quantitative terms, with specific focus on the most relevant classes of the agroforestry territory, since it represents an important part of semi-natural habitats with a high naturalistic value (Calaciura \& Spinelli, 2008).

\section{Materials and methods}

\subsection{Case studies description}

Two case studies (Figure 1) included in the Basilicata Region (South of Italy) have been considered. They present territorial diversity both from a morphological and climatic point of view. The territory is mainly occupied by forests (almost 40\%) and the agricultural sector is still an important component of the regional economy (I.Stat, 2020a). Precisely, because of the morphololgical and socio-economic diversity, agricultural systems are differentiated and distributed differently in the region. Arable land (which accounts for $61 \%$ of the utilised agricultural area) is mainly located in the hilly and flat land and in particular in the eastern part of region, while pastures ( $29 \%$ of utilised agricultural area) mainly affect inland mountain areas with rough orography (I.Stat, 2020b). This type of agriculture, which is traditional and not very intensive, has also influenced the built-up rural heritage (Cillis et al., 2019b). As in many other areas of the Mediterranean region, over the last century, the agricultural landscape of Basilicata has undergone significant transformations. Some areas have been specialized in high value agricultural production thanks to the conditions of accessibility and fertility, in others areas instead there is a more modern and industrial agriculture. Some other areas have remained linked to a "poor and familiar" rural economy (especially in the mountainous area) that are now undergoing a major transformation due to the abandonment of agriculture (European Network for Rural Development, 2020). In these areas, the small farms (Guiomar et al., 2018) that characterised the local and traditional economy are gradually disappearing. 

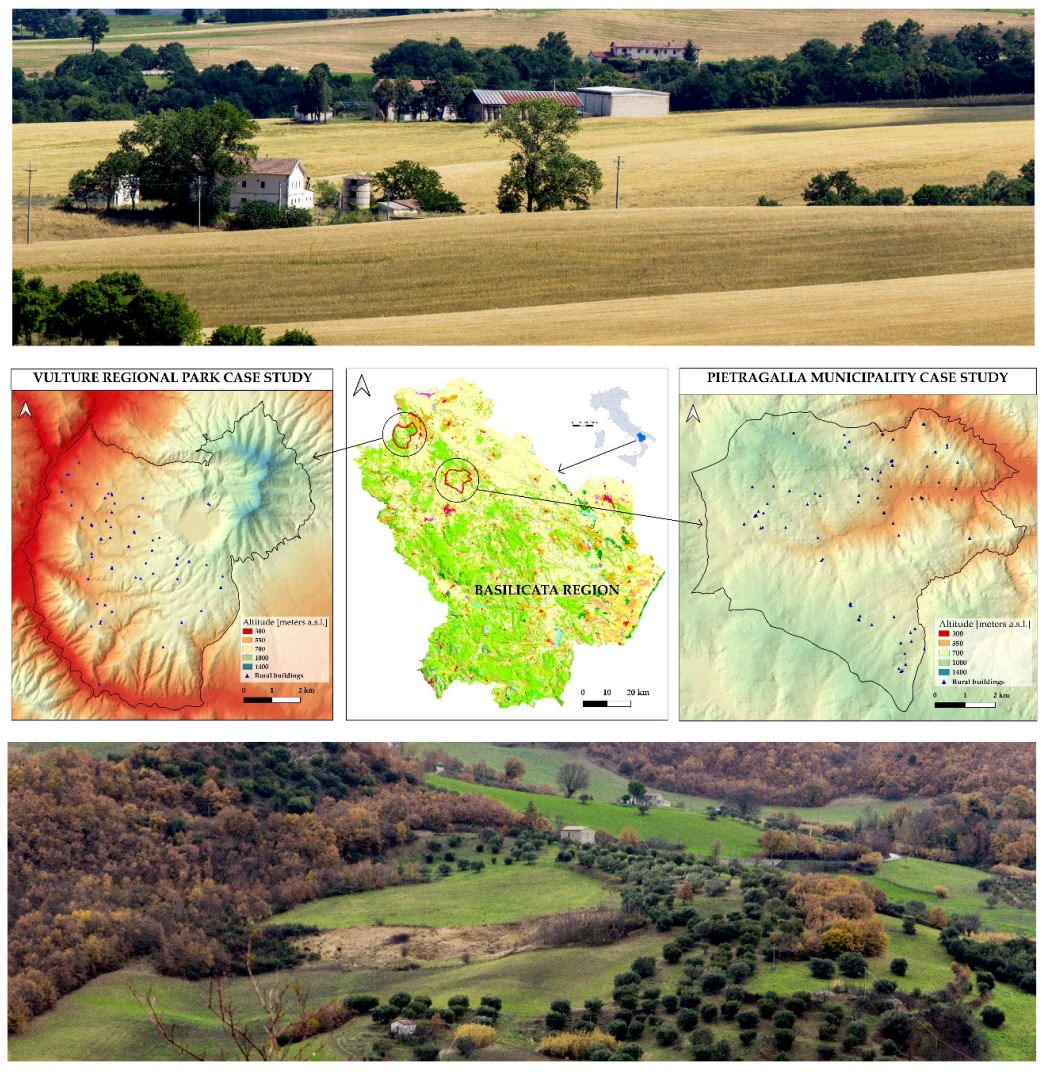

Figure 1. Locations of case studies in Basilicata region: Vulture Regional Park case study (centroid 15.58966E 40.92240 N EPSG:4326) on the top; Pietragalla case study (centroid 15.85332E 40.75722N EPSG:4326) on the bottom

The first case study concerns the municipal territory of Pietragalla (Case PTG) and it spans about $65 \mathrm{~km}^{2}$. It represents a typical territory of the marginal mountain areas of the Mediterranean and, for this reason, it was chosen as a typical example. This municipality is characterized by areas not "contaminated" by agricultural mechanization processes that continue to flank the regions affected by modernization and where agricultural systems have evolved slowly, leaving visible traces of pre-existing settlements and production conditions. This has also influenced the characteristics and development of rural buildings, which are distributed uniformly throughout the territory without aggregation. Moreover, from a typological and architectural point of view, they are simple buildings for daily or seasonal stay - therefore, for a temporary use. Moreover, this kind of territory is affected by significant phenomenon of land and agricultural abandonment (Statuto et al., 2017).

The second case study (Case VUL) represents another situation typical of these marginal mountain areas but which, thanks to specific morphological, pedological and microclimatic conditions, have had a different agricultural history (Manniello et al., 2020). Currently, the process of land abandonment is slower than in other territorial contexts. Moreover, this area (about $67 \mathrm{~km}^{2}$ ) partially falls within the perimeter of the "Vulture" Regional Park, which has been analysed in a previous work (Statuto et al., 2020). Also in this case, the rural buildings heritage has been influenced by more extensive and profitable agricultural activities. This has led to the creation of rural agglomerates in different areas of the
Vulture Park, with specific forms of colonial management or small fortresses (Franciosa, 1942) around which other types of minor rural buildings with modern characteristics, that have been restored or built ex-novo.

\subsection{Preliminary and mapping elaborations}

The complete analysis was based on 4 years of study (1955-1988-2008-2017) so as to cover the period with greater dynamics of transformation and for which it is possible to retrieve comparable datasets for large-scale analysis. All operations have been carried out only in FoSS (Free and Open Source Software) environment within an open-source Geographical Information System (QGIS 3.10) which, thanks to different plugins and interoperability with other software, allows a workflow in a single environment (Gobbi et al., 2019). This approach guarantees the possibility to integrate different types of data from historical cartography with datasets from classical cartography to remote sensed data (aerial photos, orthophotos and satellite images) (Statuto et al., 2019a).

The first operation was to create the rural heritage geodatabase for the study areas. Using the vector open data available in Basilicata region (RSDI, 2020) database, it was possible to select only those buildings that are considered as "agricultural" due to the presence of specific attributes linked to each feature. In detail, 79 rural buildings were selected in Case PTG and 66 in Case VUL. Finally, a further selection was made on the basis of the historical 

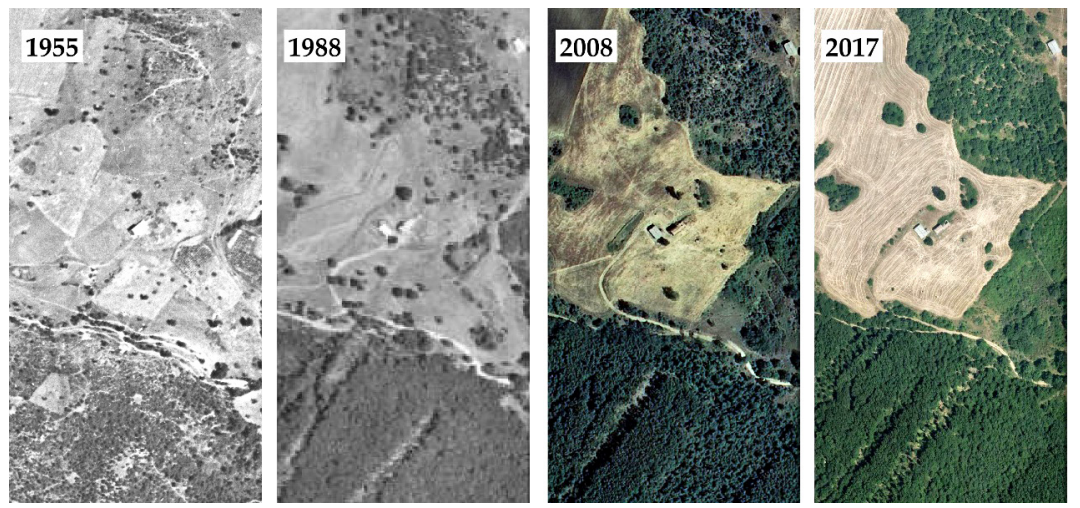

Figure 2. Sample details extract from Case PTG on some remote sensed data used in this study: 1955 aerial photo, 1988 B/W orthophoto, 2008 and 2017 true colors orthophotos

continuity of the buildings, only the rural buildings that are certainly present in the 62 years of analysis were selected. Subsequently, considering the objective of studying the relationships between the rural building and the surrounding land, a square buffer of 25 ha around the centroid of each rural building, both those isolated and those close to each other, was taken as the sample area, as it was proposed in other works (McKenzie et al., 2011; Cillis et al., 2020b, 2019b). Before mapping the ground cover, the various cartographies, aerial photos, orthophotos and satellite images were retrieved and processed (Figure 2), so as to be implemented into the GIS.

Historical aerial photos as privileged sources to assess the "significance" of individual landscape data. But, like any historical source, it needs to be properly contextualized and analyzed, in order to be able to critically grasp the limits and potentiality of the information contained.

Considering the characteristics of each historical data, a different approach is needed for each one in order to assess its usability and to reduce the errors that can result from manual or semi-automatic digitisation. In fact, for a correct land use/cover analysis with this methodology, several aspects have to be taken into account, such as: definition of the minimum mapping unit (Burnett \& Blaschke, 2003), the impossibility to verify the thematic attribution to the different cartographic elements and the different resolutions to which the elaborations are made (Turner et al., 1989). But, on the other hand, the use of maps obtained from the manual digitization of historical supports represents the only possibility to retrieve information about the spatial configuration of the territory in the past (Geri et al., 2010; Pindozzi et al., 2016). Finally, it is always necessary to calculate and take into account the errors related to the rectification and georeferencing of historical geodata in order to be aware of possible limitations in their use (Liu et al., 2018; Gobbi et al., 2018).

Considering the differences in the used basic data, preprocessing operations were carried out for each year in order to create starting raster, on which the digitisation and manual classification of land cover classes were subsequently carried out (Table 1). We opted for this type of mapping considering the reduced surfaces and the need to
Table 1. Land cover classes used for mapping operations

\begin{tabular}{|c|c|c|}
\hline $\begin{array}{c}\text { Land cover } \\
\text { Class }\end{array}$ & Acronym & Description \\
\hline $\begin{array}{l}\text { Rural } \\
\text { buildings }\end{array}$ & RUR & $\begin{array}{l}\text { Constructions classified as } \\
\text { "agricultural" in Basilicata region } \\
\text { geodatabase (RSDI, 2020). Comprises } \\
\text { several categories of rural buildings } \\
\text { (rural dwellings, temporary } \\
\text { dwellings, stables and warehouses). }\end{array}$ \\
\hline $\begin{array}{l}\text { Road } \\
\text { network }\end{array}$ & ROAD & $\begin{array}{l}\text { Stable roadway and a width of more } \\
\text { than } 6 \text { metres. Comprises the main } \\
\text { road network. }\end{array}$ \\
\hline Forest area & FOR & $\begin{array}{l}\text { Forests and woodland area with } \\
\text { a composition of autochthonous } \\
\text { Mediterranean species. }\end{array}$ \\
\hline $\begin{array}{l}\text { Afforested } \\
\text { area }\end{array}$ & AFFOR & $\begin{array}{l}\text { Area with exotic conifers and } \\
\text { allochthonous species planted by } \\
\text { men. }\end{array}$ \\
\hline Grasslands & GRASS & $\begin{array}{l}\text { Natural grasslands often associated } \\
\text { with non-cultivated areas. Often } \\
\text { located in rugged and sloping land. } \\
\text { Often includes rocky ground, moors } \\
\text { and occasional pastures. They do } \\
\text { not have constant and long-term } \\
\text { management and are not of artificial } \\
\text { origin. }\end{array}$ \\
\hline $\begin{array}{l}\text { Arable } \\
\text { lands }\end{array}$ & ARAB & $\begin{array}{l}\text { Cultivated land with different crops } \\
\text { (cereals, legumes or fodder crops). }\end{array}$ \\
\hline Vineyards & VIN & Vineyards. \\
\hline $\begin{array}{l}\text { Olive } \\
\text { groves }\end{array}$ & OLIV & Olive groves. \\
\hline Shrubland & SHRUB & $\begin{array}{l}\text { Vegetation with low cover, } \\
\text { dominated by bushes, shrubs. }\end{array}$ \\
\hline $\begin{array}{l}\text { Transitio- } \\
\text { nal wood- } \\
\text { land }\end{array}$ & TRANS & $\begin{array}{l}\text { It can represent either woodland } \\
\text { degradation or forest regeneration/ } \\
\text { colonisation. Class representing } \\
\text { natural development of forest } \\
\text { formations, consisting of young } \\
\text { trees species, shrubs, dispersed } \\
\text { solitary adult trees and herbaceous } \\
\text { vegetation. }\end{array}$ \\
\hline $\begin{array}{l}\text { Built-up } \\
\text { area }\end{array}$ & BUILT & $\begin{array}{l}\text { Built-up areas realised by man } \\
\text { (buildings and connected surfaces). } \\
\text { Rural buildings are excluded, as they } \\
\text { represent a separate class. }\end{array}$ \\
\hline
\end{tabular}


End of Table 1

\begin{tabular}{|l|l|l|}
\hline $\begin{array}{c}\text { Land cover } \\
\text { Class }\end{array}$ & Acronym & \multicolumn{1}{c|}{ Description } \\
\hline River zone & RIV & $\begin{array}{l}\text { "Atella" River area and the riparian } \\
\text { vegetation existing along the river. }\end{array}$ \\
\hline $\begin{array}{l}\text { Chestnut } \\
\text { forest }\end{array}$ & CHEST & $\begin{array}{l}\text { Forest areas made up of chestnut } \\
\text { trees. It has been separated from } \\
\text { the forest area because the "chestnut } \\
\text { forest" is a typical feature of study } \\
\text { area. They have an artificial origin, } \\
\text { but over time they have become a } \\
\text { semi-natural habitat. }\end{array}$ \\
\hline
\end{tabular}

have a degree of detail and accuracy that with semi-automatic classifications is more complicated to be obtained. The land cover map so obtained has a Minimum Mapping Unit (MMU) of 0.01 ha, which corresponds to the smallest rural building.

\subsubsection{5 dataset}

After the II World War the Italian Military Geographic Institute [IGMI] commissioned a series of flights over the whole Italy to survey the national territory. The relevance of this dataset lies in the fact that these are the first stereoscopic photos of the Italian region. The frames $(230 \mathrm{~mm}$ $\times 230 \mathrm{mmm}$ ) were scanned at a resolution of $1200 \mathrm{dpi}$. The height of the flight was around $6000 \mathrm{~m}$ a.s.l. and in Basilicata region the flights were made during the month in May 1955. The approximate scale is $1: 33,000$ (IGMI, 2020). Rectification and georeferencing process of these frames were not easy, because the calibration certificate of the camera was not available. Different methodologies have been proposed and tested for the orthorectification of this type of frames (Gobbi et al., 2018). Considering that study areas are limited in terms of surface area, and do not present particular morphology and characteristics, a series of geo-referencing operations were carried out for each group of rural buildings, identifying, time by time, a sufficient number of Ground Control Points (GCP) on more recent orthophotos (1988-2017) already geo-referenced. A polynomial correction was applied in series, that guaranteed Root Mean Square Error even below 5 meters in some cases. This operation has produced several georeferenced rasters, each one associated and clipped with respect to the buffer of each individual rural building.

After this operation, the land cover classes (Table 1) were mapped by manual digitisation. Also for this operation, it is possible to carry out semi-automatic classification operations, but given the reduced surface areas, the manual procedure has been chosen as more speditive (Gobbi et al., 2019) in order to improve the identification of the different classes, the 1:25,000 scale maps of the 1955 IGM were also used as an additional support.

\subsubsection{8 dataset}

For the year 1988, the orthophotos already georeferenced supplied by the Italian Ministry of the Environment (WMS service) have been used. These orthophotos are in 1:10,000 scale. Satellite images have been used to improve classification and especially to distinguish land cover classes that may be difficult to interpret. They have been used to distinguish arable lands from grasslands, which in many cases, and considering the period when orthophotos are taken, are difficult to differentiate in some situations. Specifically, satellite images of the Landsat 5 TM mission of several months and in correspondence with the different phenological periods of the vegetation were used (Lanorte et al., 2015; Filizzola et al., 2018). These have been downloaded, pre- and post- processed directly in QGIS by Semi-Automatic Classification Plugin (Congedo, 2016). This step allowed to discriminate the grasslands from the cereal areas which were then digitized manually.

\subsubsection{8 dataset}

To process the 2008 dataset, AGEA (Italian Agency for Agricultural Payments) orthophotos already georeferenced through the WMS service provided by the Basilicata Region were used. Also in this case, the manual classification of cereal fields and pastures was helped through the integration with Landsat 5 TM satellite images.

\subsubsection{7 dataset}

For the year 2017, AGEA already georeferenced AGEA orthophotos have been used, to which Sentinel-2 L2A images have been associated. In this case, the integration was more efficient, thanks to the characteristics and usability of these satellite images for purposes related to crop detection (Belgiu \& Csillik, 2018).

\subsection{Spatial and statistical analysis}

After mapping the land cover for each year of study and for each rural building buffer, a first generic evaluation of the territorial patterns was carried out through a quantitative analysis of the areas in terms of hectares (Figure 3). On the basis of these data, an immediate survey was carried out through the Sharpe Index (Hulshoff, 1995), that allows to easily understand what were the main changes of a given land or landscape in a certain period of time, since this index gives the measure of the "speed" - or, rather, the intensity - of the territorial transformations. The Sharpe index is applied to individual types or classes of land cover, and can be either positive or negative. If this value assumes a positive value, we are in presence of a land cover that has recorded an increase in area in the reference period, while if the value assumes a negative sign, the land cover in question has reduced its surface. This index is very useful to quickly identify the land cover most responsible for the changes in a certain period. Since Sharpe's index does not highlight the extent of different land uses in terms of hectares, a more detailed analysis was carried out through the cross-classification directly between vectors to identify the quantitative transformation trajectories of each land cover class for the periods 1955-1988, 1988-2008, 2008-2017. In addition to the data tabulation, Sankey diagrams were produces (Cuba, 2015). 


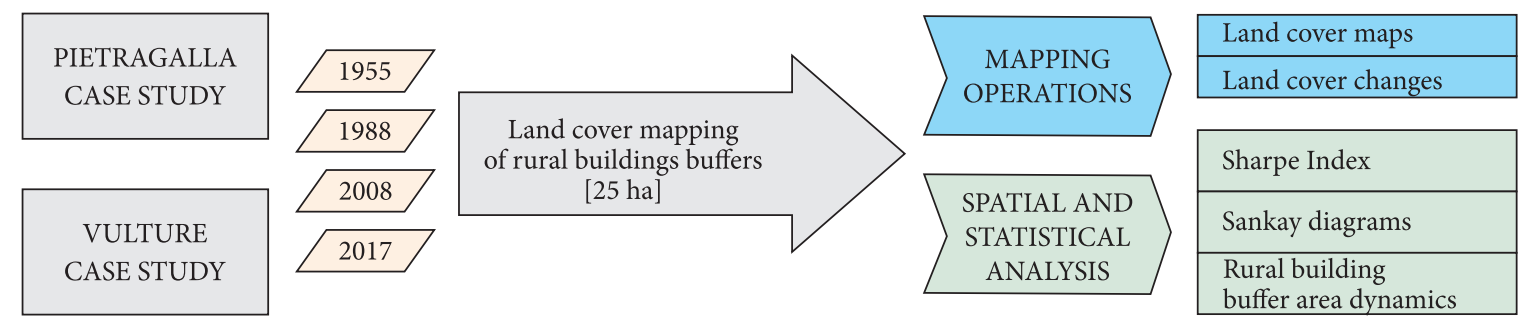

Figure 3. Flowchart to summarize the main steps of the research

It is a graphical approach to show the land cover data contained in one or more cross-tabulation matrices based on Sankey's diagrams, which simplifies visual interpretation and efficiently translates land cover changes over multiple time intervals. The graphical visualization of land cover dynamics with Sankey diagrams does not remove the usefulness of reporting detailed measures of land cover dynamics in tabular form, but rather gives benefits that are complementary to those of cross-tabulation matrices.

To answer the question: have the transformations occurred equally around every rural building? the \% of "change" and "no change" in each buffer has been calculated individually. This allows a kind of discrimination enabling to provide information about areas and farm buildings that need more attention from a land management point of view. In addition, it is possible to obtain general statistics to evaluate how the ratio between changed and unchanging areas varies for the different periods of analysis (1955-1988; 1988-2008; 2008-2017).

By imposing the $50 \%$ value as a limit, rural buildings buffers have been identified for the two case studies that have undergone, in the three periods, a change in terms of surface area greater than $50 \%$. The limit in this statistical discrimination could be determined by a specific land indicator that a public decision-maker can use based on objectives and needs.

Finally, for a first survey on the causes of the transformation phenomena in the areas surrounding some rural buildings buffers, these (selecting those with changes greater than 50\%) have been related to the slope raster, which has been calculated starting from the Digital Terrain Model DTM at 5 meters resolution (RSDI, 2020). Being a preliminary investigation, only the slope was considered, as it represents one of the main drivers in the abandonment processes (Cillis et al., 2020a). This approach has been applied only to Case PTG, as it is the case study where areas with intense changes are most prevalent and numerically evident. This analysis also presupposes a statistical evaluation, so a box plot has been made to highlight how the slope varies with respect to the periods of change and where no changes have occurred. Thanks to the use of DataPlotly (DataPlotly, 2020) a QGIS plugin, it has been possible to realize the boxplot, working directly on the shapefiles and without changing the working environment.

\section{Results}

\subsection{Agroforestry land cover dynamics}

The land cover maps produced for the four different chronological levels, in which the relevant areas for each land cover class (expressed in ha and \%) are summarized, are shown in Figure 4 and 5. These data are also shown in Table 2 and Table 3, where the net change for each timelapse was also calculated for the whole 62-years period.
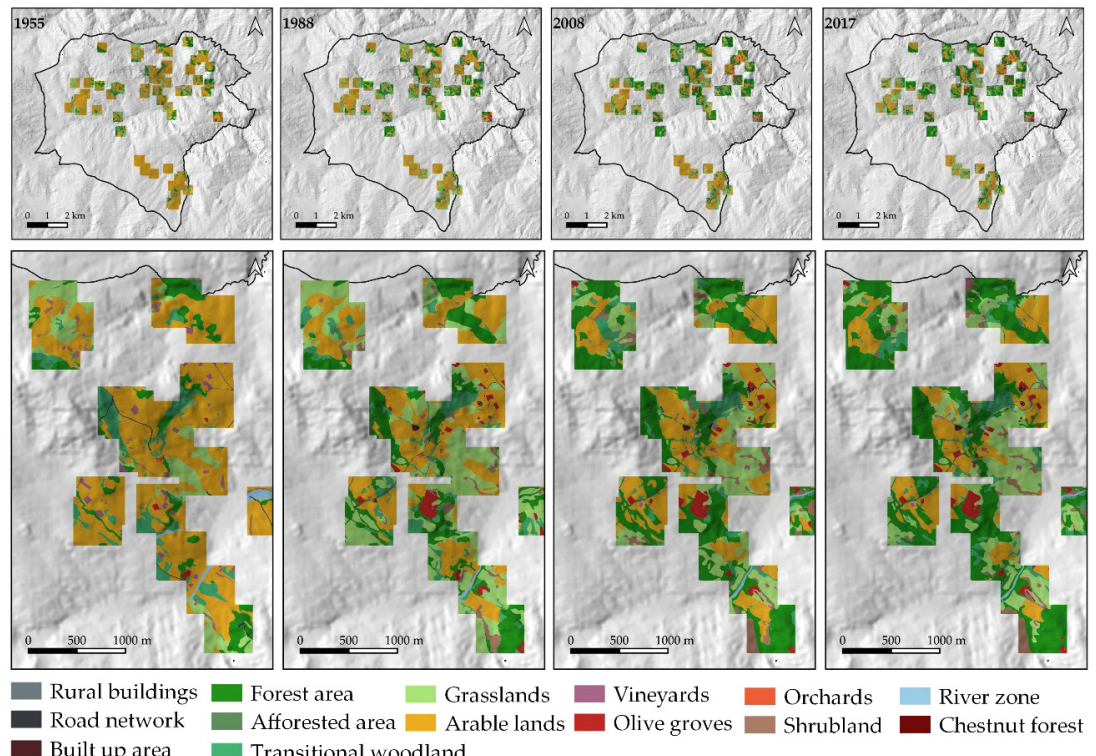

Figure 4. Land cover map for the Case PTG. A general overview of the boundary of the municipality analyzed and below a detail of some buffers 


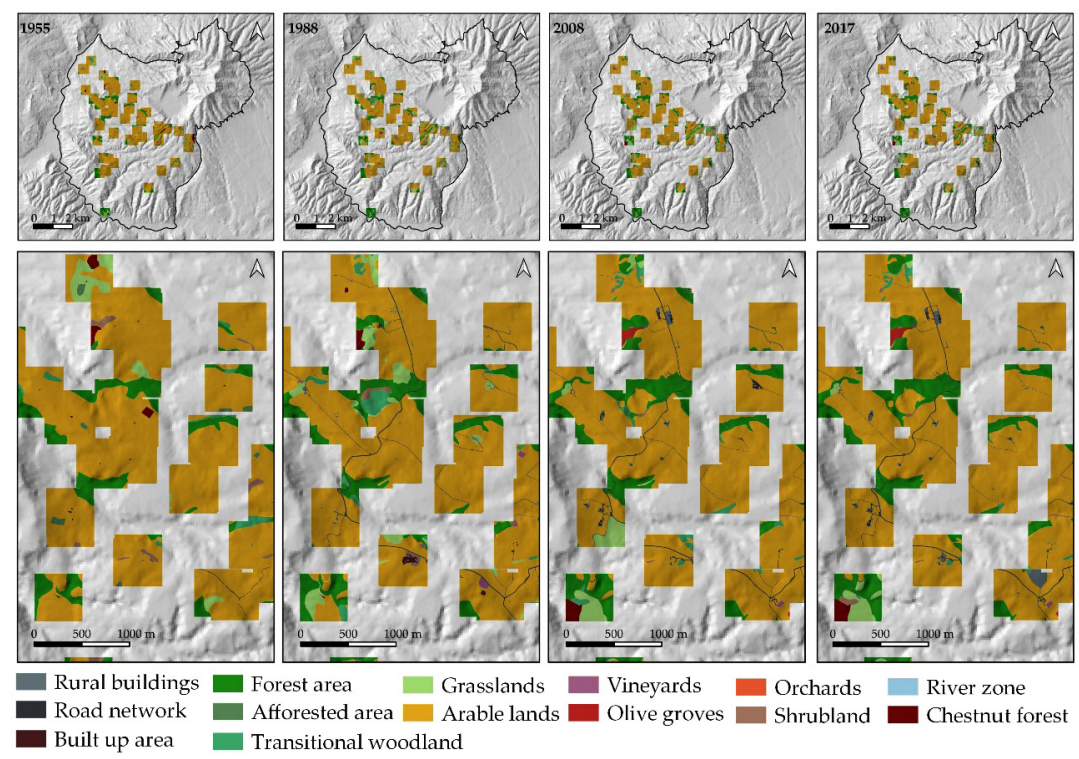

Figure 5. Land cover map for the Case VUL. A general overview of the boundary of the municipality analyzed and below a detail of some buffers

Table 2. Total surface for each land cover class (expressed in ha and \%) over the years for Case PTG. For land cover classes acronyms, see Table 1

\begin{tabular}{|c|c|c|c|c|c|c|c|c|}
\hline \multirow{2}{*}{} & \multicolumn{2}{|c|}{1955} & \multicolumn{2}{c|}{1988} & \multicolumn{3}{c|}{2008} & \multicolumn{2}{c|}{2017} \\
\cline { 2 - 9 } & ha & $\%$ & ha & $\%$ & ha & $\%$ & ha & 3.18 \\
\hline RUR & 1.82 & 0.15 & 2.78 & 0.23 & 3.04 & 0.25 & 1.26 \\
\hline ROAD & 8.56 & 0.69 & 13.06 & 1.06 & 12.51 & 1.01 & 12.70 & 1.03 \\
\hline FOR & 155.22 & 12.59 & 244.76 & 19.85 & 361.67 & 29.33 & 395.21 & 32.05 \\
\hline GRAS & 123.83 & 10.04 & 304.01 & 24.65 & 212.97 & 17.27 & 283.75 & 23.01 \\
\hline ARAB & 815.28 & 66.11 & 516.60 & 41.89 & 455.61 & 36.95 & 339.39 & 27.52 \\
\hline VIN & 9.38 & 0.76 & 7.98 & 0.65 & 9.50 & 0.77 & 11.44 & 0.93 \\
\hline OLI & 7.30 & 0.59 & 30.80 & 2.50 & 40.71 & 3.30 & 39.91 & 3.24 \\
\hline ORC & 0.65 & 0.05 & 2.20 & 0.18 & 11.49 & 0.93 & 12.26 & 0.99 \\
\hline SHUR & 14.91 & 1.21 & 34.54 & 2.80 & 53.73 & 4.36 & 54.49 & 4.42 \\
\hline TRANS & 87.48 & 7.09 & 73.75 & 5.98 & 67.08 & 5.44 & 73.88 & 5.99 \\
\hline BUILT & 0.00 & 0.00 & 1.53 & 0.12 & 2.94 & 0.24 & 5.15 & 0.42 \\
\hline RIV & 8.76 & 0.71 & 1.17 & 0.09 & 1.94 & 0.16 & 1.83 & 0.15 \\
\hline & 1233.18 & 100.00 & 1233.18 & 100.00 & 1233.18 & 100 & 1233.18 & 100 \\
\hline
\end{tabular}

Table 3. Total surface for each land cover class (expressed in ha and \%) over the years for Case VUL. For land cover classes acronyms, see Table 1

\begin{tabular}{|c|c|c|c|c|c|c|c|c|}
\hline & \multicolumn{2}{|c|}{1955} & \multicolumn{2}{|c|}{1988} & \multicolumn{2}{|c|}{2008} & \multicolumn{2}{|c|}{2017} \\
\hline & ha & $\%$ & ha & $\%$ & ha & $\%$ & ha & $\%$ \\
\hline RUR & 0.65 & 0.07 & 2.35 & 0.24 & 2.06 & 0.21 & 8.30 & 0.84 \\
\hline ROAD & 4.89 & 0.50 & 12.54 & 1.27 & 20.12 & 2.04 & 19.82 & 2.01 \\
\hline FOR & 102.74 & 10.42 & 127.36 & 12.92 & 146.03 & 14.81 & 156.70 & 15.90 \\
\hline GRAS & 36.28 & 3.68 & 59.91 & 6.08 & 51.99 & 5.27 & 86.68 & 8.79 \\
\hline ARAB & 788.21 & 79.96 & 722.58 & 73.30 & 706.37 & 71.66 & 655.02 & 66.45 \\
\hline VIN & 1.42 & 0.14 & 2.49 & 0.25 & 1.34 & 0.14 & 1.47 & 0.15 \\
\hline
\end{tabular}


End of Table 3

\begin{tabular}{|c|c|c|c|c|c|c|c|c|}
\hline \multirow{2}{*}{} & \multicolumn{2}{|c|}{1955} & \multicolumn{2}{c|}{1988} & \multicolumn{3}{c|}{2008} & \multicolumn{2}{c|}{2017} \\
\cline { 2 - 9 } & ha & $\%$ & ha & $\%$ & ha & $\%$ & ha & \% \\
\hline OLI & 0.00 & 0.00 & 0.00 & 0.00 & 2.06 & 0.21 & 2.30 & 0.23 \\
\hline ORC & 0.00 & 0.00 & 0.00 & 0.00 & 0.00 & 0.00 & 0.00 & 0.00 \\
\hline SHUR & 11.63 & 1.18 & 12.16 & 1.23 & 13.57 & 1.38 & 21.52 & 2.18 \\
\hline TRANS & 22.75 & 2.31 & 35.24 & 3.58 & 31.73 & 3.22 & 23.48 & 2.38 \\
\hline BUILT & 0.70 & 0.07 & 4.52 & 0.46 & 3.15 & 0.32 & 3.05 & 0.31 \\
\hline RIV & 1.96 & 0.20 & 1.00 & 0.10 & 1.42 & 0.14 & 1.42 & 0.14 \\
\hline CHES & 10.68 & 1.08 & 2.18 & 0.22 & 3.13 & 0.32 & 3.13 & 0.32 \\
\hline AFF & 3.83 & 0.39 & 3.39 & 0.34 & 2.77 & 0.28 & 2.87 & 0.29 \\
\hline & 985.73 & 100.00 & 985.73 & 100.00 & 985.73 & 100.00 & 985.73 & 100 \\
\hline
\end{tabular}

The analysis enabled through the identification of the general dynamics of the agroforestry land of the study, shows that some areas have radically changed during the whole 62 -years period of time considered.

From the analysis of the tables and graphs, it emerges for both case studies, that rural buildings buffers are mostly covered by agricultural areas (Figure 6). In particular, in Case VUL, arable lands covered around $80 \%$ of the total in 1955 and the value, during the 62 years of analysis, does not decrease drastically having reduce to around $66 \%$ in the year 2017. Unlike what happened in Case PTG, where between 1955 and 1988, arable lands decreased from 815.28 ha to 516.60 ha, with a drastic reduction that continued in the following years. In addition,
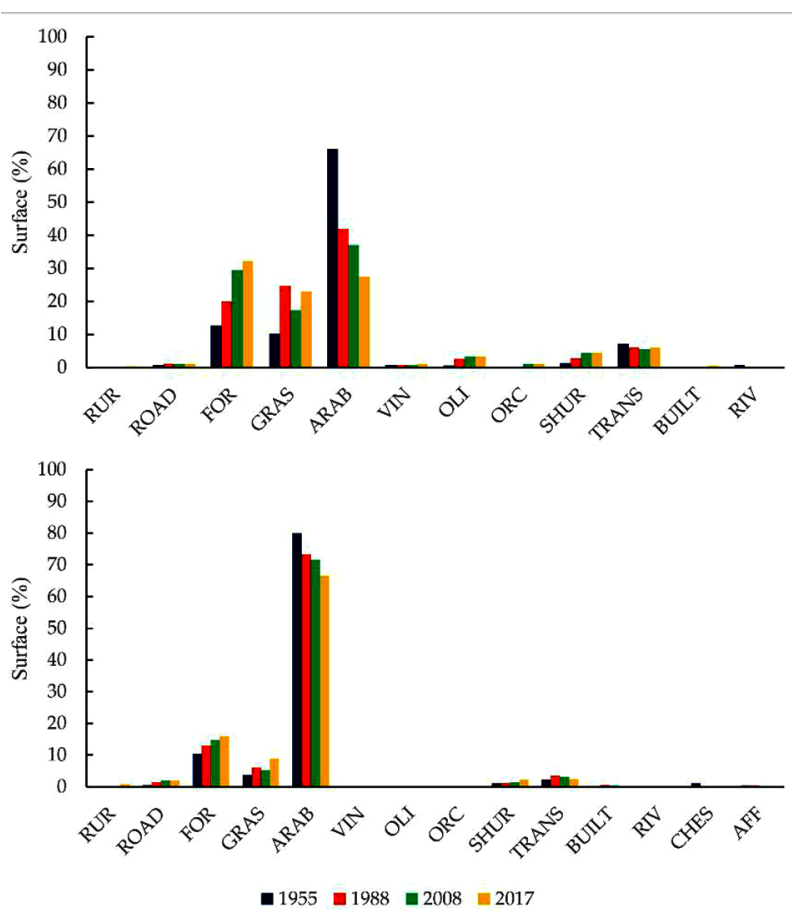

Figure 6. Land cover histograms (in percent) for different years of analysis. Case PTG on top and Case VUL on bottom the difference in the land pattern between the two cases immediately emerges, because for Case PTG there is a greater complexity and heterogeneity due to the greater distribution of other land cover classes.

The datasets need a comparative analysis by couple of years progressive to assess how the land has evolved. A first and intuitive indication on which are the classes of land cover that have most influenced the transformations is given by the Sharpe index (Figure 7). In fact it emerges that the land cover classes most affected by the dynamics are, for both cases, arable lands, grasslands, shrublands and transitional woodlands. Moreover, also the trend of the positive and negative values of the single classes is similar even if with different entities. This is further confirmation that the dynamics are generally similar in both the two study areas, but with different orders of magnitude. A substantial difference that emerges from the graphs of the two case studies is that, in Case VUL, two classes of coverage that have determined a substantial transformation are also those related to rural buildings and roads, demonstrating an increase in anthropic pressure on these areas.

In order to allow a more detailed analysis, a contingency matrix has been created. This is a type of detection of the changes obtained through a cross-tabulation analysis, which allows to highlight the changes occurred over time both in qualitative terms - showing them directly on the map - and in quantitative terms, allowing the calculation of the total extension of the land cover change occurred at different times. Through the direct geoprocessing of vector data, it was possible to exploit the functionality of the Group Stats plugin (Group Stats, 2020) which allows to realize a vector-based cross-tabulation matrix for each period of analysis and then export the results to a table (Table S1-S6 in Supplementary material). The tables created show the proportion (hectares) of unchanged area for each land cover class for each time-lapse (on the diagonal), as well as changes from one land cover class to another (off the diagonal). The rows show the areas each land cover class has transformed into the relevant class reported in the columns in the period analysed. For 


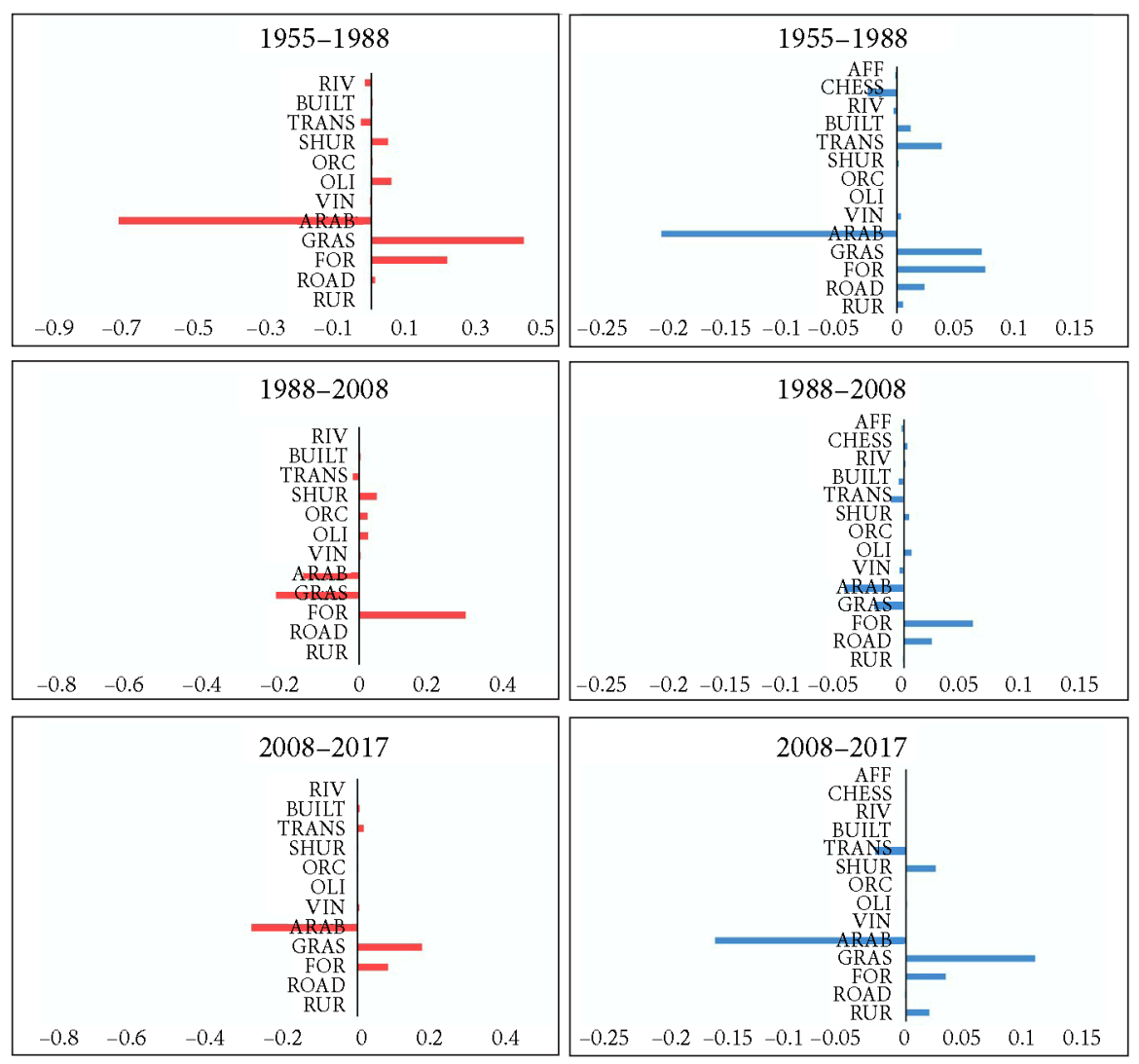

Figure 7. Sharpe index visualization. Case PTG (left) and Case VUL (right)

example, concerning the Case PTG (Table S1-S3), it is noted that in the period 1955-1988, a surface of 205.32 ha of arable lands turned into grasslands and another part (about $60 \mathrm{ha}$ ) into forest area. The last ones have increased both because of the abandonment of agricultural areas, but also because of the natural succession of about 45 ha of transitional woodlands, which have been restored by other processes of abandonment of agricultural areas and natural evolution of grasslands and shrubs. There is also a modest increase in artificial land cover classes, farm buildings and roads. This anthropization process has occurred almost exclusively at the expense of agricultural areas (almost 9 ha). In the second period (1988-2008) the dynamics are more or less similar in terms of general trends, but concerning lower surface areas, even because to a period more short than the previous one, as well as because the transformation processes slowed down, since most of the agricultural land was lost in the previous period. What increased considerably is the interchange between the classes of land cover typical of a territory defined as agropastoral forest (FOR, SHRUB, GRASS and TRANS). In fact, even if in terms of total area, the areas do not vary much, within these classes there is a high dynamism; this is due to the natural phases of ecological succession and renaturalization of abandoned agricultural areas and partly to the reduction of pastures that has led to an acceleration of the transformation processes in FOR and TRANS (Bracchetti et al., 2012). As far as artificial built-up areas and rural buildings are concerned, there are no substantial variations. For the third period (2008-2017), apart from a further transformation of 119 ha between arable lands and grasslands, there is some stability both in terms of areas and in terms of dynamism between the different land cover classes.

As far as the river zone is concerned, it can be noted that only in the year 1955 it had a significant surface weight (almost 9 ha). Over the years, the approximately 7 ha of river zone have been lost and they have been transformed mainly into forest (specifically into hygrophilous forest vegetation); the riverbed has been reduced consequently to the reduction of water flow from the surrounding areas, which in the past were mostly agricultural areas, and which over time have become forest or shrubland areas which incorporate part of the rainwater.

The Case VUL (Table S4-S6) shows a difference between the first period (1955-1988) and the next two. In fact, during the first period it can be seen the most important transformation that mainly involved the agricultural areas, which became 50 ha of grasslands and almost 20 ha of forest area. In this case study, there are also chestnut forests, which have an important productive importance; in fact, in this period there has been a substantial increase with a conversion of forest area to agricultural areas. In addition, there was a first important increase of artificial surfaces and in particular of built up area (about 4 ha) and roads (almost $8 \mathrm{ha}$ ) at the expense of arable lands, 
demonstrating the increase in infrastructure and the viability around rural buildings (also significantly increased). Overall assessing the dynamics of the three periods, it can be seen that, in general, the trend is similar to the first case study, but with lower and limited speed and range, therefore with a greater stability of land cover over the years. Also in this case, the classes of land cover linked to the transformations of natural and semi-natural habitats (GRASS, SHRUB, TRANS) are the most dynamic.

For a qualitative assessment of the data of the matrices previously mentioned and for an immediate analysis

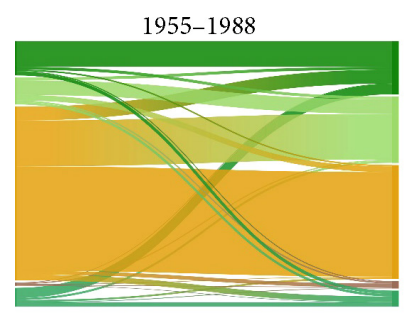

$1988-2008$

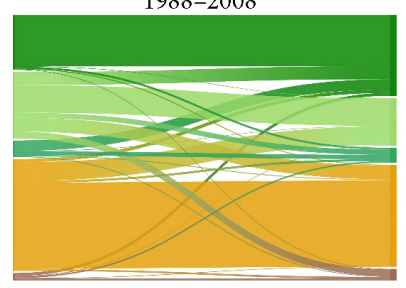

$2008-2017$

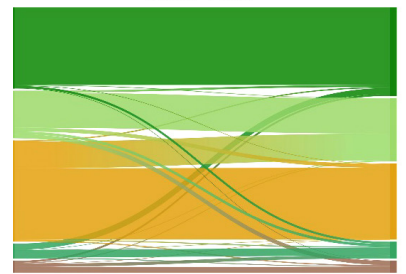

- Forest area Grasslands Arable lands

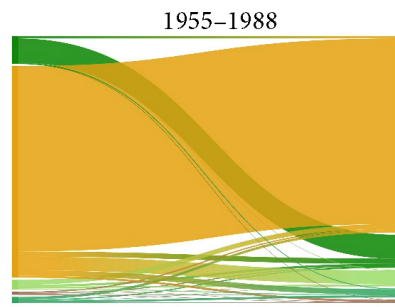

$1988-2008$

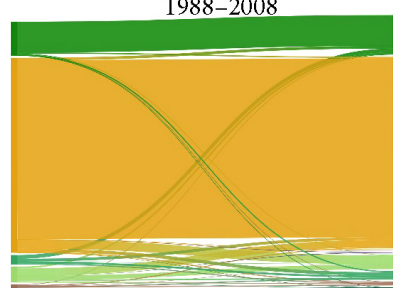

2008-2017

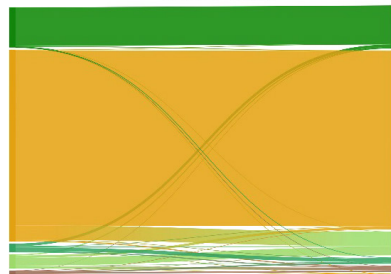

Shrubland Transitional woo

Figure 8. Sankey diagram for the dynamics of transformation of the main classes of agroforestry land cover for the three study periods. Case PTG on the left, Case VUL on the right of the tabular data, Sankey diagrams have been created (Figure 8) to track the changes occurred in the three periods of analysis and for both case studies. Considering the number of classes used, the resolution of the data, and analyzing the transition matrices, it was preferred to make the diagram only for the most dynamic classes, which are also those of interest from an agroforestry point of view.

These classes refer to arable lands, forest area, shrublands, grasslands and transitional woodlands, which represent important coverage classes for the evaluation of the evolution of natural and semi-natural habitats typical of Mediterranean rural landscapes (Cillis et al., 2019a) and which are the ones that have most influenced the transformations as also emerged from the Sharpe index.

\subsection{Rural building buffer area dynamics}

Figure 9 and Table 4 show how in Case PTG, rural buildings whose buffer area has changed more than $50 \%$ are more evident than in Case VUL. But what is most noticeable, is that the major changes between rural buildings and territory occurred in the period 1955-1988, when in $34 \%$ of the buffers these important changes in land cover occurred. In the other periods the data in Table 5 show how (also the Case VUL) the land cover changes occurred in a distributed way in all rural buildings buffers and only in a few situations (with maximum values around 7.5\%) there was a radical change within rural buildings buffers.

Finally, analysing the boxplot (Figure 10) highlighting the relationship between slope (in degree) and rural buildings buffer, in which the surface area has changed more than $50 \%$, it can be noticed that in the first two periods (1955-1988 and 1988-2008) most of the rural buildings buffer changes are within very high slope values. This situation can be compared to the values in the buffer of rural buildings which did not change, that in addition to presenting a much greater variability, have a median around $11^{\circ}$ compared to almost $14-15^{\circ}$ of the changed areas.
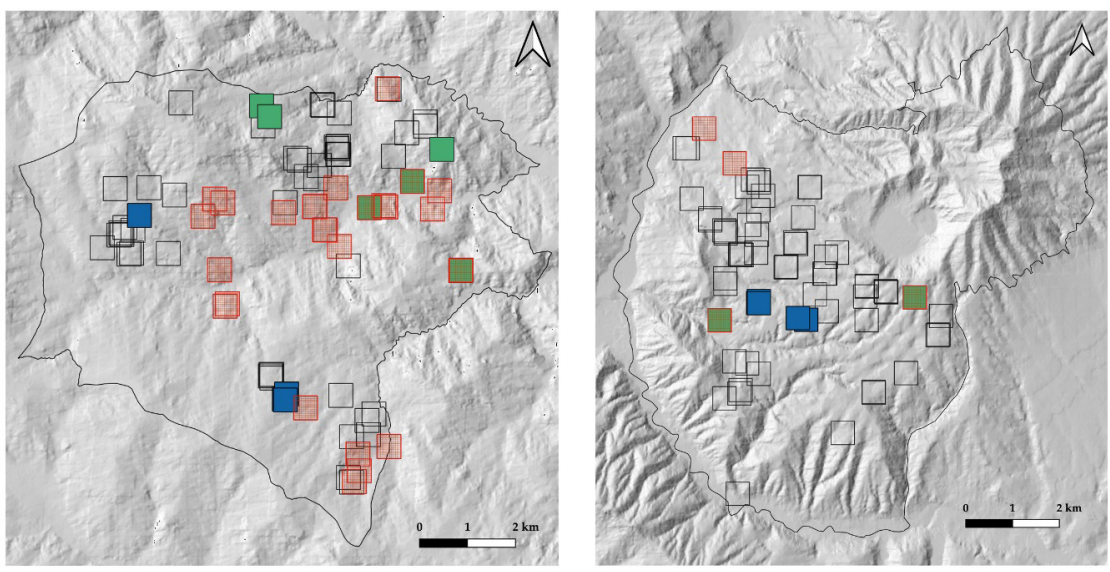

RURAL BUILDINGS BUFFER WITH CHANGES GREATER THAN $50 \%$

\section{5-1988 $\square$ 1988-2008 $\square$ 2008-2017}

Other rural buildings without important changes

Figure 9. Rural buildings buffer with changes greater than $50 \%$ and other without important changes $(<50 \%)$.

Case PTG on the left and Case VUL on the right 
Table 4. Number of rural buildings whose buffer area changed more than $50 \%$ during the three analysis periods and for the two case studies. The percentage refers to the total number of rural building buffers

\begin{tabular}{|l|c|c|c|c|}
\hline \multirow{2}{*}{} & \multicolumn{2}{|c|}{ Case PTG } & \multicolumn{2}{c|}{ Case VUL } \\
\cline { 2 - 5 } & $\mathrm{n}$. & $\%$ & $\mathrm{n}$. & $\%$ \\
\hline $1955-1988$ & 27 & 34.2 & 4 & 6.1 \\
\hline $1988-2008$ & 6 & 7.6 & 2 & 3.0 \\
\hline $2008-2017$ & 4 & 5.1 & 5 & 7.5 \\
\hline $\begin{array}{l}\text { Total n. Rural } \\
\text { buildings }\end{array}$ & 79 & & 66 & \\
\hline
\end{tabular}

An unusual situation is recorded on the few areas changed in the period 2008-2007, in which the values are much lower than the other cases and in which the specific motivations should be analysed individually taking into account also other drivers.

\section{Discussion}

As highlighted by the obtained results, the study shows that the territory, during the 62 years of analysis, has changed in both case studies and in line with the trend that has occurred in many inland areas of the Mediterranean region and especially along the Italian Apennines (Malandra et al., 2018). In particular, the main typical dynamics are related to the reduction of agricultural areas in favour to natural areas. Within these natural areas, on the other hand, the dynamics are different in relation to the context and the individual classes of considered land cover; after an initial transformation into grasslands, the abandonment processes continued until many areas were transformed into forests. This shows that, in addition to the loss of agricultural activity and the cultivation of cereals, all those agricultural activities linked to free grazing have been reduced over the years. This last process is much more evident in the Case PTG case study because the rural heritage was mainly realized for grazing purposes and, therefore, the abandonment of this form of agricultural activity (Quaranta et al., 2020) has led to much more intense and rapid transformations than Case VUL. In fact, while in 1955 the area surrounding the farm buildings was largely occupied by cultivated land, in 2017 the forest became the main element of the territory. The most intense abandonment certainly took place between 1955 and 1988; this is due both to the duration of the period analysed and to the different processes described (Picuno et al., 2019).

Analyzing the time interval from 1988 to 2008, it can be seen that in addition to the high dynamism of the natural and semi-natural land cover classes, agricultural activity has slightly diversified thanks to the transformation of cultivated land into vineyards and olive groves, certainly representing the period in which there has been a greater heterogeneity of the land due mainly to the different levels of ecological succession that have originated in abandoned arable land. In the last period (2008-2017) the intensity of the transformation and abandonment processes in the territory surrounding the farms has decreased, since there has been less transformation of the agricultural areas, which have stabilized in more favourable and profitable parts of the territory in terms of accessibility and soil quality. On the contrary, the areas around farms that most have changed are those with the steepest slopes. This phenomenon, which has also occurred in other (Statuto et al., 2017) territorial contexts, is mainly due to changes in socio-economic conditions and in European agricultural policy, that have made it less convenient to cultivate the lower productive parts of inland areas. Besides considering other factors (both morphological and socioeconomic), a methodology to improve the analysis is to consider individually the different categories of land cover change (Peña-Angulo et al., 2019).

Evaluating in greater detail the transformations that have occurred, in addition to the processes of

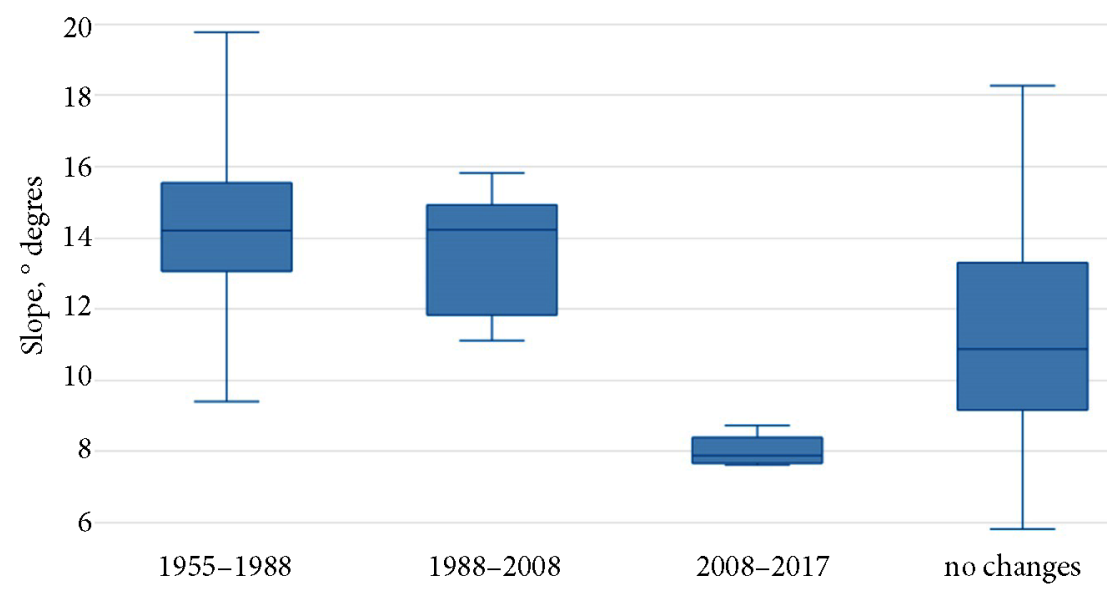

Figure 10. Box plots of the relationships between slope with rural buildings buffer with changes greater than $50 \%$ of surface for the three analysed periods and with rural buildings buffer (no changes) with few changes. Horizontal lines inside the box indicate the median value of each parameter. The bottom of the box is at the first quartile ( $25 \%$ of distribution), and the top is at the third quartile ( $75 \%$ of distribution) value, while whiskers indicate variability outside the upper and the lower quartiles 
abandonment of the cultivation of cereals, it is important to consider the transformation processes of the prairies, which have become semi-natural habitats of the highest naturalistic value (Alard et al., 1994; Cousins, 2009). The abandonment of agricultural activity by farmers and consequently also the same rural buildings have led in many contexts to an advancement of the forest and a homogenization of the agroforestry territory to the detriment of dry grasslands with high biodiversity, i.e. those semi-natural habitats of Community interest linked to grazing (priority habitats Natura2000 code $6210^{\star}$ ). These particular situations require in-depth study and field surveys in order to be able to assess them individually. In addition, this approach can be integrated into predictive models for local forest protection against climate change (Viccaro et al., 2019) or provide data to assess how some agricultural practices have affected High Nature Value agroforestry (Almeida et al., 2016) systems such as those analysed in this study.

Therefore, an overall assessment of the relationship between land transformation and rural buildings in the two case studies shows that in both situations there is a phenomenon of abandonment of agricultural areas, with consequent loss of semi-natural habitats in favour of forest habitats only. However, this process has been more intense in the Case PTG where the built rural heritage is simpler and linked to seasonal use, it is an expression of a more traditional type of agriculture on a small scale and often familiar that, considering the current economic crisis of this sector and the concurrent process of depopulation, has led to the complete abandonment of areas less favourable to this type of agriculture. In the Case VUL, an area that in any case suffers from depopulation and economic crisis (I.Stat, 2019), this process seems to proceed more slowly, both thanks to the characteristics of the territory and to the type of agriculture that has historically settled (with larger and less fragmented land and larger rural settlements distributed in strategic points of the territory).

Finally, considering the variability of the intensity and speed of the transformations occurred in the two case studies, it is necessary, in order to study the relationship between territory and rural buildings, to have a diversified approach according to the territorial context of reference, adapting the analysis methodologies in relation to the environmental, landscape and economic characteristics of the individual areas. From a technical point of view, however, the methodology used, even if applied on a small area, can be useful to understand how the landscape around farms has been transformed, identifying mainly those farms that play an important ecological role within the agroforestry territory. Moreover, the construction of a geodatabase that includes rural buildings has made it possible to carry out spatial mapping and geostatistical evaluations. From the methodological point of view, the transition matrices, thanks to their ability to highlight both macro and micro changes, are certainly one of the tools that could be adopted by the planners of the territory. These tools, associated with the dynamic Sankey diagrams, in which it is possible to view in an interactive way also the tabular data, allow to make cross-tabulation analysis simpler and more efficient, easily usable by public administrations.

The methodology applied in this study can be understood as a first synthetic approach for the territorial analyses developed and the basis for a study of the relationship between changes in the territory and the built rural heritage. To this end, a simple buffer was used to standardise the survey, but for a more in-depth analysis it may be possible to evaluate the relationship with the cadastral parcels associated with each rural building, in order to include administrative and economic data in the analysis. The research is based on a study area (Basilicata Region) that presents some peculiar characteristics. These, however, can be found in other similar mountain and marginal areas. Therefore, in areas characterised by a similar agroforestry land both in terms of ecological and morphological structure, with a non-intensive agricultural activity linked to small areas and to a traditional rural building heritage and by an intense land abandonment that implies an increase in the forest surface, this approach can potentially be applicable also in other study areas. Furthermore, given the characteristics of the geodata and the fact that the tools are totally open source, the techniques can also be replicated and even partly improved in relation to specific needs.

\section{Conclusions}

The results which have been obtained in this paper show that farm buildings represent a fundamental pillar for the sustainable management of the agroforestry land, since they cover the most marginal hilly and mountainous areas of the Mediterranean regions, play a fundamental role for conservation, management and monitoring of land and landscape with high naturalist value. Moreover, there is also a relationship between the intensity of land abandonment and the type of rural heritage. Therefore, it can be very useful to introduce rural buildings as a qualitative factor in the analysis of the elements that explain the abandonment of agricultural areas as well.

This methodology can be implemented at different levels as a management and decision-making support tool for the different territorial governance. In fact, the simplicity of the methodologies, the interoperability between the different techniques and the possibility to realize semi-automatic systems thanks to open source GIS tools, make the use of territorial data for the study of the territory more immediate. Open source software, in particular the QGIS, provide all the necessary tools to operate and process the types of geographical data needed for spatial studies, allowing to simplify operations and improving the accuracy of the analysis. In addition, they allow a quick and simplified use of satellite images that in the past required much more specialized applications and techniques, difficult to integrate in GIS environment. 
Finally, thanks to the possibility of model builder and batch processing of the GIS software, once the areas and objectives have been identified, it is possible to carry out further investigations in series, repeating them over time, in order to speed up certain operations and create a system to support spatial decisions.

\section{References}

Alard, D., Bance, J.-F., \& Frileux, P.-N. (1994). Grassland vegetation as an indicator of the main agro-ecological factors in a rural landscape: Consequences for biodiversity and wildlife conservation in Central Normandy (France). Journal of Environmental Management, 42(2), 91-109.

https://doi.org/10.1006/jema.1994.1063

Almeida, M., Azeda, C., Guiomar, N., \& Pinto-Correia, T. (2016). The effects of grazing management in montado fragmentation and heterogeneity. Agroforest Systems, 90, 69-85. https://doi.org/10.1007/s10457-014-9778-2

Amici, V., Maccherini, S., Santi, E., Torri, D., Vergari, F., \& Del Monte, M. (2017). Long-term patterns of change in a vanishing cultural landscape: A GIS-based assessment. Ecological Informatics, 37, 38-51.

https://doi.org/10.1016/j.ecoinf.2016.11.008

Baldantoni, P., Nolè, G., Lanorte, A., Tucci, B., Santarsiero, V., \& Murgante, B. (2019). Trend definition of soil consumption in the period 1994-2014 - Municipalities of Potenza, Matera and Melfi. In S. Misra et al. (Eds.), Lecture notes in computer science: Vol. 11621. Computational science and its applications - ICCSA 2019. ICCSA 2019. Springer, Cham. https://doi.org/10.1007/978-3-030-24302-9_49

Belda-Carrasco, R., Iranzo-García, E., \& Pascual-Aguilar, J. (2019). Landscape dynamics in mediterranean coastal areas: Castelló De La Plana in the last hundred years. Landscape Online, 69, 1-15. https://doi.org/10.3097/LO.201969

Belgiu, M., \& Csillik, O. (2018). Sentinel-2 cropland mapping using pixel-based and object-based time-weighted. Remote Sensing of Environment, 204, 509-523.

https://doi.org/10.1016/j.rse.2017.10.005

Bracchetti, L., Carotenuto, L., \& Catorci, A. (2012). Land-cover changes in a remote area of central Apennines (Italy) and management directions. Landscape and Urban Planning, 104(2), 157-170.

https://doi.org/10.1016/j.landurbplan.2011.09.005

Burgess, P. J., \& Rosati, A. (2018). Advances in European agroforestry: results from the AGFORWARD project. Agroforestry Systems, 92, 801-810.

https://doi.org/10.1007/s10457-018-0261-3

Buttoud, G., Ajayi, O. C., Detlefsen, G., Place, F., \& Torquebiau, E. F. (2013). Advancing agroforestry on the policy agenda: a guide for decision-makers (Agroforestry working paper no 1). Food and Agriculture Organization of the United Nations. FAO, Rome.

Burnett, C., \& Blaschke, T. (2003). A multi-scale segmentation/ object relationship modelling methodology for landscape analysis. Ecological Modelling, 168, 233-249. https://doi.org/10.1016/S0304-3800(03)00139-X

Calaciura, B., \& Spinelli, O. (2008). Management of Natura 2000 habitats. 6210 Semi-natural dry grasslands and scrubland facies on calcareous substrates (Festuco-Brometalia) (* important orchid sites). European Commission.

Cillis, G., Statuto, D., \& Picuno, P. (2020b). Spatial analysis of the impact of rural buildings on the agroforestry landscape using
GIS. Lecture Notes in Civil Engineering, 67, 207-214.

https://doi.org/10.1007/978-3-030-39299-4_23

Cillis, G., Statuto, D., \& Picuno, P. (2019a). Historical maps processed into a GIS for the assessment of forest landscape dynamics. In Public recreation and landscape protection - With Sense Hand in Hand? Conference Proceeding 2019 (pp. 180184).

Cillis, G., Statuto, D., \& Picuno, P. (2019b, March 5-7). Valorisation of historical farm buildings for protecting the rural landscape. In Proceedings of the 47th Symposium on: Actual Tasks on Agricultural Engineering - ATAE 2109 (pp. 535-544). Opatija, Croatia.

Cillis, G., Statuto, D., \& Picuno, P. (2020a). Vernacular farm buildings and rural landscape: A geospatial approach for their integrated management. Sustainability, 12, 4. https://doi.org/10.3390/su12010004

Congedo, L. (2016). Semi-automatic classification plugin documentation. https://doi.org/10.13140/RG.2.2.29474.02242/1

Cousins, S. A. O. (2009). Landscape history and soil properties affect grassland decline and plant species richness in rural landscapes. Biological Conservation, 142(11), 2752-2758. https://doi.org/10.1016/j.biocon.2009.07.001

Cuba, N. (2015). Research note: Sankey diagrams for visualizing land cover dynamics. Landscape and Urban Planning, 139, 163-167. https://doi.org/10.1016/j.landurbplan.2015.03.010

DataPlotly. (2020). https://github.com/ghtmtt/DataPlotly

De Montis, A., Martín, B., Ortega, E., Ledda, A., \& Serra, V. (2017). Landscape fragmentation in Mediterranean Europe: A comparative approach. Land Use Policy, 64, 83-94. https://doi.org/10.1016/j.landusepol.2017.02.028

European Network for Rural Development. (2020). Rivista Rurale Unione Europea, (17). https://enrd.ec.europa.eu/sites/ enrd/files/PublicationENRDperiodical-17_it.pdf

Filizzola, C., Corrado, R., Falconieri, A., Faruolo, M., Genzano, N., Lisi, M., Mazzeo, G., Paciello, R., Pergola, N., \& Tramutoli, V. (2018). On the use of temporal vegetation indices in support of eligibility controls for EU aids in agriculture. International Journal of Remote Sensing, 39(14), 4572-4598. https://doi.org/10.1080/01431161.2017.1395973

Franciosa, L. (1942). La casa rurale nella Lucania [In The rural house in Lucania Region]. Ohlski (in Italian).

Geri F., Rocchini, D., \& Chiarucci, A. (2010). Landscape metrics and topographical determinants of large-scale forest dynamics in a Mediterranean landscape. Landscape and Urban Planning, 95(1-2), 46-53.

https://doi.org/10.1016/j.landurbplan.2009.12.001

Gobbi, S., Cantiani, M. G., Rocchini, D., Zatelli, P., Tattoni, C., La Porta, N., \& Ciolli, M. (2019). Fine spatial scale modelling of Trentino past forest landscape (Trentino land): a case study of FOSS Application. International Archives of the Photogrammetry, Remote Sensing and Spatial Information Sciences, XLII-4/ W14, 71-78.

https://doi.org/10.5194/isprs-archives-XLII-4-W14-71-2019

Gobbi, S., Maimeri, G., Tattoni, C., Cantiani, M. G., Rocchini, D., La Porta, N., Ciolli, M., \& Zatelli, P. (2018). Orthorectification of a large dataset of historical aerial images: procedure and precision assessment in an open source environment, International Archives of the Photogrammetry, Remote Sensing and Spatial Information Sciences, XLII-4/W8, 53-59.

https://doi.org/10.5194/isprs-archives-XLII-4-W8-53-2018

González-Puente, M., Campos, M., McCall, M. K., \& MuñozRojas, J. (2014). Places beyond maps; integrating spatial map analysis and perception studies to unravel landscape change 
in a Mediterranean mountain area (NE Spain). Applied Geography, 52, 182-190.

https://doi.org/10.1016/j.apgeog.2014.05.010

Group Stats. (2020). https://github.com/HenrikSpa/GroupStats

Guiomar, N., Godinho, S., Pinto-Correia, T., Almeida, M., Bartolini, F., Bezák, P., Biró, M., Bjørkhaug, H., Bojnec, Š., Brunori, G., Corazzin, M., Czekaj, M., Davidova, S., Kania, J., Kristensen, S., Marraccini, E., Molnár,, Z., Niedermayr, J., O’Rourke, E., Ortiz-Miranda, D., Redman, M., Sipiläinen, T., Sooväli-Sepping, H., Šūmane, S., Surová, D., Sutherland, L. A., Tcherkezova, E., Tisenkopfs, T., Tsiligiridis, T., Tudor, M. M., Wagner, K., \& Wästfelt, A. (2018). Typology and distribution of small farms in Europe: Towards a better picture. Land Use Policy, 75, 784-798.

https://doi.org/10.1016/j.landusepol.2018.04.012

Haller, A., \& Bender, O. (2018). Among rewilding mountains: Grassland conservation and abandoned settlements in the Northern Apennines. Landscape Research, 43(8), 1068-1084. https://doi.org/10.1080/01426397.2018.1495183

Hillbrand, A., Borelli, S., Conigliaro, M., \& Olivier, E. (2017). Agroforestry for landscape restoration. Exploring the potential of agroforestry to enhance the sustainability and resilience of degraded landscapes. FAO, Rome, Italy.

Hulshoff, M. R. (1995). Landscape indices describing a Dutch landscape. Landscape Ecology, 10(2), 101-111. https://doi.org/10.1007/BF00153827

Italian Military Geographic Institute. (2020). https://www.igmi. org/it/descrizione-prodotti/aerial-photography/black-andwhite-or-colour-aerial-photographs

I.Stat. (2019). Statistiche I.Stat - Italian population statistics. http://dati.istat.it/Index.aspx

I.Stat. (2020a). Statistiche I.Stat. https://www.arcgis.com/apps/ MapJournal/index.html?appid=6d59671694ef44559f416fd51 2b9f274

I.Stat. (2020b). Censimento agricoltura 2010. http://dati-censimentoagricoltura.istat.it/Index.aspx

Lanorte, A., Manzi, T., Nolè, G., \& Lasaponara, R. (2015). On the use of the Principal Component Analysis (PCA) for evaluating vegetation anomalies from LANDSAT-TM NDVI Temporal Series in the Basilicata Region (Italy). In O. Gervasi et al. (Eds.), Lecture Notes in Computer Science: Vol. 9158. Computational Science and Its Applications - ICCSA 2015. ICCSA 2015. Springer, Cham.

https://doi.org/10.1007/978-3-319-21410-8_16

Lanorte, A., De Santis, F., Nolè, G., Blanco, I., Loisi, R. V., Schettini, E., \& Vox, G. (2017). Agricultural plastic waste spatial estimation by Landsat 8 satellite images. Computers and Electronics in Agriculture, 141, 35-45.

https://doi.org/10.1016/j.compag.2017.07.003

Lasco, R. D., Delfino, R. J. P., Catacutan, D. C., Simelton, E. S., \& Wilson, D. M. (2014). Climate risk adaptation by smallholder farmers: the roles of trees and agroforestry. Current Opinion in Environmental Sustainability, 6, 83-88.

https://doi.org/10.1016/j.cosust.2013.11.013.

Ledda, A., Serra, V., \& De Montis, A. (2019). The effect of rural buildings on landscape fragmentation in Natura 2000 sites: A case study in Sardinia. Sustainability, 11, 4695.

https://doi.org/10.3390/su11174695

Liu, D., Toman, E., Fuller, Z., Chen, G., Londo, A., Zhang, X., \& Zhao, K. (2018). Integration of historical map and aerial imagery to characterize long-term land-use change and landscape dynamics: An object-based analysis via Random Forests. Ecological Indicators, 95(1), 595-605.

https://doi.org/10.1016/j.ecolind.2018.08.004
Malandra, F., Vitali, A., \& Urbinati, C. (2019). Patterns and drivers of forest landscape change in the Apennines range, Italy. Regional Environmental Change, 19, 1973-1985.

https://doi.org/10.1007/s10113-019-01531-6

Malandra, F., Vitali, A., Urbinati, C., \& Garbarino, M. (2018). 70 years of land use/land cover changes in the Apennines (Italy): A meta-analysis. Forests, 9, 551.

https://doi.org/10.3390/f9090551

Manniello, C., Statuto, D., Di Pasquale, A., Giuratrabocchetti, G., \& Picuno, P. (2020). Planning the flows of residual biomass produced by wineries for the preservation of the rural landscape. Sustainability, 12, 847.

https://doi.org/10.3390/su12030847

McKenzie, P., Cooper, A., McCann, T., \& Rogers, D. (2011). The ecological impact of rural building on habitats in an agricultural landscape. Landscape and Urban Planning, 101, 262-268. https://doi.org/10.1016/j.landurbplan.2011.02.031

Moreno, G., Aviron, S., \& Berg, S. (2018). Agroforestry systems of high nature and cultural value in Europe: provision of commercial goods and other ecosystem services. Agroforestry Systems, 92, 877-891.

https://doi.org/10.1007/s10457-017-0126-1

Nair, P. R. (1993). An introduction to agroforestry. Springer Science \& Business Media.

https://doi.org/10.1007/978-94-011-1608-4

Pardini, A. (2009). Agroforestry systems in Italy: traditions towards modern management. In A. Rigueiro-Rodriguez, J. McAdam, \& M. R. Mosquera-Losada (Eds.), Agroforestry in Europe: current status and future prospects (pp. 255-267). Springer.

Paris, P., Camilli, F., \& Rosati, A. (2019). What is the future for agroforestry in Italy? Agroforestry Systems, 93, 2243-2256. https://doi.org/10.1007/s10457-019-00346-y

Peña-Angulo, D., Khorchani, M., Errea, P., Lasanta, T., MartínezArnáiz, M., \& Nadal-Romero, E. (2019). Factors explaining the diversity of land cover in abandoned fields in a Mediterranean mountain area. CATENA, 181, 104064. https://doi.org/10.1016/j.catena.2019.05.010

Picuno, C. A., Laković, I., Roubis, D., Picuno, P., \& Capetanović, A. (2017). Analysis of the characteristics of traditional rural constructions for animal corral in the Adriatic-Ionian area. Sustainability, 9, 1441. https://doi.org/10.3390/su9081441

Picuno, P., Cillis, G., \& Statuto, D. (2019). Investigating the time evolution of a rural landscape: How historical maps may provide environmental information when processed using a GIS. Ecological Engineering, 139, 105580.

https://doi.org/10.1016/j.ecoleng.2019.08.010

Pindozzi, S., Cervelli, E., Capolupo, A., Okello, C., \& Boccia, L. (2016). Using historical maps to analyze two hundred years of land cover changes: case study of Sorrento peninsula (south Italy). Cartography and Geographic Information Science, 43, 250-265. https://doi.org/10.1080/15230406.2015.1072736

Pinto-Correia, T., Primdahl, J., \& Pedroli, B. (2018). European landscapes in transition - implications for policy and practice. Studies in landscape ecology. Cambridge University Press. https://doi.org/10.1017/9781107707566

Quaranta, G., Salvia, R., Salvati, L., De Paola, V., Coluzzi, R., Imbrenda, V., \& Simoniello, T. (2020). Long-term impacts of grazing management on land degradation in a rural community of Southern Italy: Depopulation matters. Land Degradation \& Development, 31, 2379- 2394.

https://doi.org/10.1002/ldr.3583

Rocchini, D., Luque, S., Pettorelli, N., Bastin, L., Doktor, D., Faedi, N., Feilhauer, H., Féret, J. B., Foody, G. M., Gavish, Y., 
Godinho, S., Kunin, W. E., Lausch, A., Leitão, P. J., Marcantonio, M., Neteler, M., Ricotta, C., Schmidtlein, S., Vihervaara, P., Wegmann, M., \& Nagendra, H. (2018). Measuring $\beta$-diversity by remote sensing: A challenge for biodiversity monitoring. Methods in Ecology and Evolution, 9(8), 17871798.

https://doi.org/10.1111/2041-210X.12941

RSDI. (2020). Infrastruttura Regionale dei Dati Spaziali della Regione Basilicata. https://rsdi.regione.basilicata.it/

Saikia, P., Kumar, A., \& Khan, M. L. (2017). Agroforestry: A sustainable land use system for livelihood security and climate change mitigation. In B. C. Pandey, M. K. Gaur, \& R. K. Goyal (Eds.), Climate change and agroforestry (1st ed., pp. 61-70). New India Publishing Agency.

Santiago-Freijanes J. J., Pisanelli, A., Rois-Díaz, M., AldreyVázquez, J. A., Rigueiro-Rodríguez, A., Pantera, A., Vityi, A., Lojka, B., Ferreiro-Domínguez, N., \& Mosquera-Losada, M. R. (2018). Agroforestry development in Europe: Policy issues. Land Use Policy, 76, 144-156. https://doi.org/10.1016/j.landusepol.2018.03.014

Statuto, D., Cillis, G., \& Picuno, P. (2016). Analysis of the effects of agricultural land use change on rural environment and landscape through historical cartography and GIS tools. Journal of Agricultural Engineering, 47, 28-39. https://doi.org/10.4081/jae.2016.468

Statuto, D., Cillis, G., \& Picuno, P. (2017). Using historical maps within a GIS to analyze two centuries of rural landscape changes in Southern Italy. Land, 6, 65.

https://doi.org/10.3390/land6030065

Statuto, D., Cillis, G., \& Picuno, P. (2019a). GIS-based analysis of temporal evolution of rural landscape: A case study in Southern Italy. Natural Resources Research, 28, 61-75.

https://doi.org/10.1007/s11053-018-9402-7
Statuto, D., Cillis, G., \& Picuno, P. (2020). Assessing the impact of built heritage on the rural landscape through the integration in a GIS of cartographic information and remote-sensed data. In Public recreation and landscape protection - With sense hand in hand? Conference proceeding (pp. 63-67).

Statuto, D., \& Picuno, P. (2017). Valorisation of vernacular farm buildings for the sustainable development of rural tourism in mountain areas of the Adriatic-Ionian macro-region. Journal of Agricultural Engineering, 48(S1), 21-26. https://doi.org/10.4081/jae.2017.643

Strollo, A., Smiraglia, D., Bruno, R., Assennato, F., Congedo, L., De Fioravante, P., Giuliani, C., Marinosci, I., Riitano, N., \& Munafò, M. (2020). Land consumption in Italy. Journal of Maps, 16(1), 113-123. https://doi.org/10.1080/17445647.2020.1758808

Turner, M. G., O’Neill, R. V., Gardner, R. H., \& Milne, B. T. (1989). Effects of changing spatial scale on the analysis of landscape pattern. Landscape Ecology, 3, 153-162. https://doi.org/10.1007/BF00131534

Valerio, F., Ferreira, E., Godinho, S., Pita, R., Mira, A., Fernandes, N., \& Santos, S. M. (2020). Predicting microhabitat suitability for an endangered small mammal using Sentinel-2 Data. Remote Sensing, 12, 562. https://doi.org/10.3390/rs12030562

Van Tricht, K., Gobin, A., Gilliams, S., \& Piccard, I. (2018). Synergistic use of radar Sentinel-1 and optical Sentinel-2 imagery for crop mapping: A case study for Belgium. Remote Sensing, 10, 1642. https://doi.org/10.3390/rs10101642

Viccaro M., Cozzi, M., Fanelli, L., \& Romano, S. (2019). Spatial modelling approach to evaluate the economic impacts of climate change on forests at a local scale. Ecological Indicators, 106, 105523. https://doi.org/10.1016/j.ecolind.2019.105523 